\title{
Singularidades nacionais e lógica do mercado: o Golpe de 1964 no Brasil nas páginas da revista argentina Panorama
}

\author{
Helder Gordim da Silveira ${ }^{1}$
}

\begin{abstract}
Resumo: O artigo busca examinar a repercussão da consolidação da ditadura no Brasil como notícia internacional na Argentina por meio do estudo de caso da revista Panorama, fundada e dirigida por Cesare Civita. Desenvolve-se, com base no conceito de ideologia e de construção social dos acontecimentos, a hipótese de que a veiculação de tais notícias, desde a posição e a atuação político-institucional da imprensa informativa empresarial, concorreu para a legitimação da solução autoritária na crise política argentina, apresentando o caso do Brasil como exemplar.
\end{abstract}

Palavras Chave: Imprensa,Ditadura Civil-Militar,Argentina-Brasil

\section{National singularities and market logic: 1964' coup in Brazil through the pages of the argentinian magazine Panorama}

\begin{abstract}
The article seeks to examine the repercussion of the consolidation of the dictatorship in Brazil as international news in Argentina through the case study of Panorama magazine, founded and directed by Cesare Civita. Based on the concept of ideology and social construction of facts, the hypothesis is that the dissemination of such news, considering the stance and the political-institutional procedure of the business press, contributed to legitimize the authoritarian solution in the Argentine political crisis, presenting the case of Brazil as an example.
\end{abstract}

Key Words: Press, Civilian-Military Dictatorship, Argentine-Brazil

Artigo recebido em: 15/10/2019

Artigo aprovado para publicação em: 24/01/2020

\footnotetext{
${ }^{1}$ Doutor em História das Sociedades Ibéricas e Americanas, Pontifícia Universidade Católica do Rio Grande do Sul, Projeto "Informação e Ideologia: o Golpe de 1964 no Brasil como Notícia na Grande Imprensa do Cone Sul", Av. Ipiranga 6681, Escola de Humanidades PUCRS, Porto Alegre RS, helders@pucrs.br.
} 


\section{Introdução}

O presente artigo constitui um resultado de um projeto de pesquisa que busca examinar a repercussão ideológica do Golpe de Estado e do regime ditatorial implantado no Brasil, em 1964, na imprensa informativa empresarial argentina. Desse universo de pesquisa, destaca-se aqui a revista Panorama, publicada pela Editora Abril, fundada e dirigida por Cesare Civita, na construção das notícias internacionais acerca daquele contexto político brasileiro.

O exame do discurso jornalístico moderno se embasou na perspectiva teórica associada ao conceito de ideologia, atualizado em Stuart Hall (HALL, 2010). O autor sustenta a possibilidade teórica de que a análise da ideologia consista na explicitação da "estrutura profunda" dos enunciados particulares, sendo tal estrutura de caráter não estritamente formal, como pressupõem posições "estruturalistas extremas", mas "histórico". Dessa forma:

\footnotetext{
a 'estrutura profunda' de um enunciado precisaria ser concebida como a rede de elementos, premissas e pressuposições derivadas dos discursos consagrados e elaborados historicamente que se acumularam ao longo dos anos, nos quais toda a história da formação social se sedimentou, e que agora constituiu um reservatório de temas e premissas nos quais (...) os emissores poderiam se inspirar para o trabalho de significar eventos novos e inquietantes (IDEM, pp. 303-304).
}

Adiante, discutiremos a forma pela qual essa noção pode embasar uma teoria acerca de "fatos", "acontecimentos" e "notícias" como categorias de análise do discurso jornalístico moderno. Nessa direção, aponta-se, por ora, para a hipótese básica aqui trabalhada, segundo a qual a construção narrativa das notícias acerca dos fatos/acontecimentos que consolidavam a ordem ditatorial no Brasil atuou potencialmente como uma ideologia da solução autoritária para a crise argentina contemporânea.

A denominação imprensa informativa empresarial se refere aos jornais diários e revistas, com forma, conteúdo e natureza organizacional resultantes da transição que se 
verifica, grosso modo, a partir das décadas finais do século dezenove, com origem marcada nos Estados Unidos e reflexos imediatos na Europa e América Latina. A organização empresarial moderna de jornais diários e revistas tem sua origem no modelo norteamericano dos penny papers, que aparecem nos anos 1830, tendo posteriormente influenciado experiências semelhantes na Europa e América Latina, até atingirem a condição de paradigma da imprensa moderna, fundada na autonomia em relação ao Estado e a organizações partidárias, no profissionalismo e na chamada objetividade informativa. O surgimento e a referida evolução da penny press é bem estudada por Michael Schudson e outros autores (HABERMAS, 2014; CHALABY, 2003; SCHUDSON, 2010).

\section{A Editoria Abril de Cesare Civita e a Revista Panorama}

O aparecimento da revista Panorama, em junho de 1963, não pode ser pensado fora do contexto empresarial e sociopolítico no qual se encontra inserida essa publicação mensal de atualidades. Trata-se da Editora Abril argentina, que teria filiais no Brasil e outros países da América Latina, e da trajetória, particularmente no país platino, do seu fundador e proprietário, o imigrante italiano Cesare Civita.

Quando surge a revista Panorama, a Argentina se encontrava sob o governo de Arturo Illia, da Unión Cívica Radical del Pueblo (UCRP), o qual estava inserido no contexto político da chamada democracia tutelada pelas Forças Armadas, desde a deposição de Perón, pela Revolución Libertadora, de 1955. A UCRP, a Unión Cívica Radical Intransigente (UCRI), liderada por Arturo Frondizi, e os principais partidos políticos nacionais (socialistas, conservadores, democrata-cristãos) disputavam o poder, na órbita federal e nas províncias, com o peronismo, o qual, embora proscrito formalmente, prosseguia uma força política ativa e organizada nos setores sindical e partidário, sob a liderança, embora por vezes discutida na militância, do seu líder maior, exilado na Espanha (CAVAROZZI, 2009; DE RIZ, 2000; DONGHI, 2000; O’DONNEL, 2004; PARADISO, 2005; ROMERO, 2001; ROUQUIEU, 1994). 
Peronismo e anti-peronismo dividiam politicamente o país de forma acentuada (GAMBINI, 2008). A Revolução em Cuba atuava como um extraordinário catalisador de tensões, com a radicalização das esquerdas e das direitas, dentro e fora do peronismo e das Forças Armadas, notando-se o surgimento do primeiro foco guerrilheiro em Tucumán, a partir de 1963.

O Exército, sob influência crescente da Doutrina de Segurança Nacional (DSN), dividia-se sobre a questão essencial que envolvia a integração versus a proscrição repressiva radical de um peronismo sem Perón, em uma ordem política estável, denominando-se os grupos militares azules e colorados, respectivamente (POTASH, 1994).

Igualmente recrudescia o conflito prático e doutrinário em torno de modelos de desenvolvimento econômico, fundados, respectivamente, na industrialização, de caráter estatizante, ou na agro exportação, de matriz liberal, sobretudo após o governo Frondizi, da UCRI (1958-1962). Este, em aliança com o peronismo proscrito, pusera em prática, até sua deposição pelos militares, uma política desenvolvimentista industrializante, pela via de abertura ao capital estrangeiro e ampla penetração do capital multinacional, de forte repercussão em variadas faces do âmbito sociocultural. A abertura do país ao mercado internacional, em contraste com a era peronista, refletia-se no cosmopolitismo que passava a marcar ambientes como a Universidade, as manifestações artísticas e o campo editorial e jornalístico (TARONCHER, 2009; ULANOVSKY, 2005). Neste, especificamente, verificava-se um boom de novas publicações, com destaque para as revistas aos moldes norte-americanos e europeus, sob a égide do chamado Novo Jornalismo e da geração de jovens oriunda dos cursos universitários, no qual, em parte, se insere a revista aqui analisada.

O governo Illia, de base política bastante frágil, sob a abstenção massiva do peronismo nas eleições (CANTIS, 1995; LLAIRÓ, 2007; GIBAJA, 2008; SÁNCHEZ, 1983), via-se assim fustigado pelo debate em torno de uma nova ordem política nacional, sendo geralmente enquadrado em uma imagem de incompetência e lentidão frente às exigências políticas que desafiavam o país. Uma nova ruptura institucional se apresentava como 
inevitável no processo de oposição da imprensa empresarial ao oficialismo, em um fenômeno caracterizado como golperiodismo por parte de um setor da literatura especializada (TARONCHER, 2009).

Bem antes desse contexto em que surge Panorama, Cesare Civita iniciara sua carreira no setor editorial, em 1936 - após experiências profissionais da juventude nos Estados Unidos e na África - na Itália, sob o regime de Mussolini, quando ingressa na empresa de Arnoldo Mondadori, editando a publicação de revistas voltadas ao público infantil com os personagens de Walt Disney. Com a edição das chamadas leis raciais, em 1938, Civita, membro da comunidade judaica, vê-se na contingência de deixar o emprego e o país, recebendo, a título indenizatório pela dissolução do contrato de trabalho, os direitos de publicação sobre os personagens e as histórias em quadrinhos que editava (SCARZANELLA, 2009 e 2016).

Seria, então, com Mickey Mouse, Pato Donald e cia. na bagagem que Cesare Civita, após passagem por Paris, Londres, Nova Iorque e Rio de Janeiro, chegaria em Buenos Aires. Era maio de 1941 e, ao longo dos trinta anos seguintes, o imigrante construiria ali um império empresarial que o colocaria no centro do setor editorial argentino. O núcleo do império seria criado no final do mesmo ano, reunindo sócios da comunidade argentina de imigrantes judeus italianos: a Editora Abril.

Voltada inicialmente ao público infanto-juvenil, a Abril publicaria a coleção Pequeños Grandes Libros, da qual faziam parte histórias com os personagens Disney, que alcançou enorme sucesso, chegando à marca de um milhão de exemplares dos livros por ano (SCARZANELLA, 2009, p. 68). Em 1944, a editora obteria os direitos para a publicação de revista exclusiva com histórias em quadrinhos dos personagens estadunidenses, a qual Civita denominou El Pato Donald, vivendo então a Argentina o primeiro ano do novo regime inaugurado pelo golpe dos coronéis, de 1943.

As relações de Civita com a nova ordem, que projetaria Juan Domingo Perón ao centro do poder, seriam marcadamente conflituosas. Apesar de estabelecer contratos com empresários de origem italiana ligados ao regime de Mussolini, notadamente no setor 
gráfico argentino, Civita ostentava posição política abertamente antifascista e de oposição ao regime, inclusive participando da publicação do semanário Itália Livre, juntamente a vários intelectuais compatriotas, dentre os quais o sociólogo Gino Germani, e oferecendo emprego a oposicionistas de esquerda.

Após a queda de Perón e o início da referida democracia tutelada pelos militares (1955-1966) - em um contexto de forte internacionalização da economia, da sociedade e da chamada cultura de massa na Argentina - a Abril intensificará seu processo de expansão, diversificando suas publicações, investindo no setor industrial gráfico e apostando na consolidação de suas posições empresariais na América Latina, com destaque para a sucursal no Brasil.

$\mathrm{Na}$ esteira do aludido processo de diversificação de publicações, para além dos quadrinhos, livros infantis e fotonovelas, surgirão duas novas revistas de sucesso: Claudia, em 1957, e a aqui importante Panorama, em junho de 1963, como referido. Sobre as duas novas revistas da Abril, refere Eugenia Scarzanella:

Claudia y Panorama ('La revista de nuestro tiempo') son termómetros de la fiebre modernizadora argentina. Se imitan revistas extranjeras (...) como antes se habían imitado los tebeos, los libros para niños y las fotonovelas, argentinizando los modelos originales. En este período aumenta el impulso a crear un producto que no sea local, sino que pueda atraer a lectores de otros países latino-americanos. No sólo (...) las nuevas publicaciones de Abril constituirán un modelo para revistas destinadas al público de lengua portuguesa de Abril brasileña, sino que Claudia y Panorama conquistarán mercados de países vecinos (Uruguay, Chile, Colombia, Perú, Centroamérica) y se creará una sociedad mixta en México, la Mexabril (2009, p. 80).

A autora sustenta que, desde o início dos anos 1950, Civita planejava editar uma revista de atualidades no estilo da italiana Epoca, do amigo Mondadori, mas que não se transformaria oportunidade concreta para tanto até 1963, quando lança Panorama, em acordo com o editor italiano e com o grupo estadunidense Time-Life (2009, p. 77). Especificamente sobre a revista, refere: 
Panorama, tal como las revistas contemporáneas Primera Plana y Confirmado, se dirige a un público [de classes alta e média] deseoso de adecuarse a los consumos y los valores de las sociedades occidentales más avanzadas. (...) Como su homólogo italiano de Mondadori, es una revista de tipo nuevo, que no apuesta ya sólo a los servicios fotográficos (dado que a ese punto la televisión ya responde de manera más eficaz que la prensa al pedido de un 'periodismo por imágenes'), sino que privilegia el texto escrito, adoptando un estilo sobrio, llevando a cabo investigaciones, brindando 'notícias incómodas'. (...) La presentación gráfica (...) mejora gracias a la importación de maquinarias italianas. Con el intento por mantener 'los hechos separados de las opiniones' como había propuesto Times antes que nadie, se aspira a 'hacer una revista que merezca el respecto de todos los sectores dirigentes del país' (2009, pp. 79-80).

Carlos Ulanovsky informa que o primeiro número de Panorama, com 132 páginas, esgotou-se em 48 horas e acrescenta:

en la edición inicial se explicaba el funcionamento de esa especie de redacción 'doble', una en Buenos Aires y otra en Nueva York, 'que selecciona material de acuerdo con las directivas enviadas desde Buenos Aires. Desde la redacción de Time, en la Avenida de las Américas, Nueva York, se despachaban hacia el sur más de dos millones de palabras'. Y desde aquí viajaban periodistas para especializarse (2005, p. 223).

Sobre as características formais e de estilo da revista, afirma o autor:

ofrecía notas en color - mucho antes que la TV cromática -, en especial la de temas extranjeros; presentaba un movimiento informativo inusual apoyado en el tratamiento in extenso de cuestiones que los diarios no trataban o a las que conferían espacios mínimos; le daba gran importancia a los enviados especiales. En el número 1 había 7 notas locales y 20 internacionales (2005, p. 223).

Ainda quanto aos aspectos técnicos e estilísticos, assevera Eugenia Scarzanella:

Do ponto de vista gráfico, Panorama era fruto dos maquinários novos importados da Itália e do modelo americano de rotogravura no qual a fotografia não era tanto um complemento ao texto, mas um instrumento autônomo de comunicação. (...) Faziam parte do novo estilo de jornalismo técnicas de montagem, inserção de elementos de documentação, ausência de continuidade narrativa e uso da língua falada. (...) Outra característica de Panorama era não se prender demais à atualidade, de refletir sobre os acontecimentos presentes e passados, olhando-os em perspectiva (2016, pp. 148-149). 
A autora destaca ainda que "Panorama era impressa no estabelecimento da rua Florida, em uma moderna rotativa que em uma hora podia imprimir 22 mil pequenos fascículos (pliegos) de 32 páginas em cores”. E “era a primeira revista argentina a usar um tipo especial de papel, o papel couché (2016, p. 145).

Destaque-se a vocação da revista, voltada ao noticiário internacional, pelo predomínio e a extensão das matérias, assim como pela utilização bastante frequente, conforme referido, de enviados especiais, o que se verá na cobertura do golpe de Estado no Brasil:

\begin{abstract}
A ambição da Abril era oferecer ao público uma revista 'global', que ampliasse o olhar dos leitores sobre o mundo, como sugeria o título e como testemunhavam os dossiês fotográficos de início de ano, que recapitulavam os acontecimentos de todo o planeta. Era dado um amplo espaço ao noticiário da Argentina, mas sem nenhum provincianismo. Ao contrário, a revista propunha a ideia de um país que fazia parte da arena internacional, com leitores conscientes e curiosos, verdadeiros cidadãos planetários, que 'além de como, desejavam saber o porquê daquilo que acontece no mundo (SCARZANELLA, 2016, p. 147).
\end{abstract}

A chefia de redação ficou inicialmente a cargo de Jorge De Ángelis, cidadão italiano, casado com a jornalista Adriana Civita, filha de Cesare, ficando a secretaria nas mãos de Carlos Velazco e Mario Enrique Ceretti. O diretor artístico da revista era o pintor Stefan Strocen. A diagramação era dirigida pelo escultor Enrique Tudó. Francisco "Paco" Vera, fotógrafo que trabalhava para a Life, era o diretor da seção de fotografias, a qual se tornaria uma referência do fotojornalismo argentino.

\title{
O Golpe no Brasil Como Notícia em Panorama
}

Para o presente artigo, foram considerados oito exemplares mensais de Panorama, entre maio e dezembro de 1964. Destes, o Brasil foi objeto de longas reportagens em três edições. Essa cobertura de Panorama do golpe de Estado no Brasil e de seus desdobramentos iniciais, ao longo do ano, segue o estilo das matérias de destaque da revista de Civita. Vê-se uma combinação de elementos da fotorreportagem apresentando imagens que, por vezes, ocupam praticamente todo o espaço da página, 
entremeadas de textos curtos alusivos àquelas - com textos longos e de forte teor analítico acerca do fato, certamente produzidos por Correspondente ou Enviado Especial, embora as matérias não tenham autoria indicada.

Como base teórico-metodológica do exame de tal material, serão utilizadas três categorias analíticas diferenciadas e inter-relacionadas: "fato", "acontecimento" e, finalmente, "notícia".

$\mathrm{O}$ "fato" pertence à ordem da exterioridade em relação ao sujeito, apresentandose para este, portanto, como um dado de natureza objetiva, ou, se assim se disser, "real". Sem adentrar detidamente no estatuto ontológico do fato, mas imediatamente afastando a ótica positivista clássica, Muniz Sodré assim o define:

\footnotetext{
é preciso ficar claro [quanto ao fato] (...) que não se trata de objeto fora da faculdade representativa do homem, e sim de objeto do conhecimento. Desta maneira são fatos as propriedades matemáticas das grandezas, assim como o objeto de qualquer experiência possível. (...) Uma 'experiência possível' comporta um objeto, (...) um 'momento' estabelecido como um correlato do sujeito. Isto não significa que de um lado esteja o sujeito da consciência com suas representações e do outro esteja o 'fato-objeto' como uma 'coisa' existente no mundo, em si, extralinguística. Os 'objetos' do conhecimento são (...) representações sensíveis interligadas e dependentes de espaço e tempo, assim como das leis da unidade da experiência, que as tornam comuns a todos. Neste sentido, dizer objeto é o mesmo que dizer 'fenômeno'. (...) O mundo dos fatos - a que podemos também chamar de 'estado de coisas' - é o mundo da experiência empírica $(2009$, p. 28).
}

Essa instância de exterioridade sempre correlata ao sujeito - a qual torna possível um saber de natureza objetiva sobre o real - é a fonte empírica para o processo por meio do qual aqueles objetos da percepção são apreendidos na consciência subjetiva, ganhando sentido e, portanto, existência significativa. Isto é, os "fatos" só podem ser concebidos e comunicados como "acontecimentos".

Miquel Alsina parece corroborar essa perspectiva de compreensão do fenômeno fato-acontecimento quando enuncia o que constituiria as três premissas básicas para uma teoria do acontecimento: 
1) Os acontecimentos são gerados através de fenômenos que são externos para o sujeito [fatos].

2) Mas os acontecimentos [fatos] não fazem sentido longe dos sujeitos, pois são eles os que lhes conferem sentido.

3) Os fenômenos externos [fatos] que o sujeito percebe tornamse acontecimento por causa da ação deste sobre aqueles. Os acontecimentos se compõem das características dos elementos externos nos quais o sujeito aplica seu conhecimento (2009, p. 114).

Parece fundamental aqui reter os dois conceitos imbricados, fato e acontecimento, nomeando-os de forma diversa, à medida que isso permite compreender o caráter rigorosamente não-ficcional da narrativa que constitui a "notícia" - o que embasa o pacto de credibilidade/veracidade que liga o jornalista a seu público-leitor.

Tal construção é geralmente pensada, no interior do campo jornalístico, em termos positivistas, que demarcam a concepção de saber na ideologia profissional da notícia. Estamos, portanto, adotando a definição de "notícia" como o resultado discursivo do processo por meio do qual o jornalista profissional seleciona e hierarquiza, a partir de critérios sistemáticos de noticiabilidade, "acontecimentos" relativos a um certo espaço temático - isto é, narrativas constituídas socialmente a partir de "fatos" - para construir nova narrativa, portanto, novo "acontecimento" (!), dentro de cânones, demandas e relações do campo, a que se põe, ou pretende pôr-se, como saber legítimo sobre a atualidade.

Assim, no intuito de proceder com uma análise desse produto essencial do jornalismo moderno em uma teoria da notícia, adotam-se aqui alguns elementos da perspectiva construtivista, fundada na tradição analítica geralmente posta como “construção social da realidade” (ALSINA, 2009, pp. 17-52; CHARADEAU, 2013, pp. 129151; SODRÉ, 2009, pp. 20-135). Convém, todavia, considerar a advertência de Nelson Traquina, aparentemente inócua se vista do interior da ideologia profissional:

o principal produto do jornalismo contemporâneo, a notícia, não é ficção, isto é, os acontecimentos ou personagens das notícias não são invenção dos jornalistas. A transgressão da fronteira entre realidade e ficção é um dos maiores pecados da profissão de jornalista, merece a 
violenta condenação da comunidade e [representa] quase o fim de qualquer promissora carreira de jornalista.

Entretanto, imediatamente o autor propõe o contraste:

dever-se-ia acrescentar rapidamente que muitas vezes essa 'realidade' é contada como uma telenovela, e aparece quase sempre em pedaços, em acontecimentos, uma avalanche de acontecimentos perante a qual os jornalistas sentem como primeira obrigação dar respostas como notícias, rigorosas e se possível confirmadas, o mais rapidamente possível, perante a tirania do fator tempo (2005, p. 20).

Assim, no que toca especificamente ao processo de construção da notícia, a concepção de ideologia profissional, envolvendo a prática institucional e o discurso jornalístico, é compatível teoricamente, ao menos em suas linhas definidoras, com a noção construtivista de Miquel Alsina a respeito do discurso e da prática jornalística como constituintes de "mundos possíveis", articulados a um "mundo real" e a um "mundo de referência":

[o mundo possível] será aquele mundo que o jornalista construirá levando em conta o mundo 'real' e um mundo de referência escolhido. Em resumo, o jornalista não pode estabelecer qualquer mundo possível, mas precisa levar em conta os fatos que ele conhece sobre o assunto que pretende relatar, e as características do mundo de referência a que os fatos o remetem. Esse mundo possível construído (...) terá as marcas pertinentes do mundo de referência (IDEM, p. 308).

Propomos que se possa razoavelmente associar tal perspectiva do autor ao conjunto da argumentação aqui exposta. Nesse sentido: o "mundo real" corresponde à teoria do "fato", acima desenvolvida; o "mundo de referência" é pensado como a "estrutura profunda" não explícita dos enunciados jornalísticos (pressupostos epistemológicos, matrizes ideológicas, modelos narrativos etc.) e o "mundo possível" encontra-se associado à teoria da "notícia", como construção discursiva típica do campo - constituinte de "acontecimentos" sui generis - como se argumentou antes.

É nessa perspectiva que será empregada a terminologia de Miquel Alsina, para afirmar-se com o autor: "se no mundo 'real' era produzida a verificação e no mundo de referência era determinada a verossimilhança, no mundo possível se desenvolve a veracidade" (Idem, p.310. Grifos meus). É assim que Miquel Alsina chama a verificação, 
a verossimilhança e a veracidade de "operações de produção de sentido", as quais denominaremos, nos termos da articulação teórica acima referida, "operações ideológicas" na produção do discurso jornalístico.

Nessa perspectiva, verifica-se, nas matérias aqui examinadas, uma articulação de dois eixos temáticos ou argumentativos. De um lado, procura-se estabelecer as razões, a natureza e os desdobramentos potenciais da crise política brasileira e do golpe como culminância dela; de outro, busca-se delinear uma imagem das características socioculturais e históricas, postas como definidoras de uma identidade nacional brasileira. Ambas as linhas argumentativas se articularão nas operações ideológicas de verificação e verossimilhança para produzir o efeito de veracidade na construção do acontecimento - jornalístico - no país vizinho.

A manchete da matéria inicial da cobertura é significativa nesse sentido: "Brasil: Gigante en Crisis" (PANORAMA, maio de 1964, p. 30). Um gigantismo e a complexidade social, histórica e cultural, potencialmente em contraste nesses aspectos com a Argentina, são sempre associados aos condicionamentos da crise política presente e suas possíveis evoluçõos futuras.

A adoção do termo "revolução", pelo qual se auto denominara o golpe no Brasil, para caracterizar a intervenção militar, remete a um mundo referencial constituído por elementos associados a um estado de crise mais ou menos profunda, por um lado, enquanto que por outro, de ruptura radical e instauradora de nova ordem política, destinada, a princípio, a perdurar no tempo. O termo "incruenta", pelo qual se adjetiva a revolução, ao mesmo tempo que expurga do acontecimento a violência, que seria "natural" em um quadro de referência consolidado a respeito de "revoluções" no Ocidente, remete à forma de reação social mais ampla ao fato "revolucionário", potencialmente classificável por passividade. A expressão "quebra financeira" remete, por seu turno, ao que é posto como a natureza essencial daquela crise, assim como as menções ao "caos administrativo" na ordem deposta - centralizada na figura de Goulart - é associada às significações negativas do termo "demagogia". 
A sub manchete que encabeça a face aprofundada da notícia dá o sentido geral da argumentação que se seguirá: “Donde También Dos Más Dos Son Cuatro” (Idem, p. 31). O leitor logo perceberá que se trata de desenvolver a informação noticiosa no sentido de apontar a causa determinante, de valor universal, para o acontecimento, a qual se coloca frente a interpretações concorrentes, supostamente embasadas em certa imagem do país vizinho, difundida por seus próprios intelectuais e meios de comunicação. Ou seja, trata o jornalista, sempre nos cânones ideológicos de seu ofício, de (re)constituir a verdade dos fatos na notícia internacional, para uma correta orientação da Opinião Pública de seu país, certamente tendo em vista, direta ou indiretamente, o contexto político interno, conjunturalmente situado-significado no governo de Arturo Illia e na tutela militar do pós-1955.

Nesse sentido, a argumentação prossegue sustendo que, se for considerada apenas a administração de Goulart, posta como "acidentada", teriam razão os analistas que colocavam o "fato revolucionário" de abril na conta da irracionalidade natural da vida pública brasileira. Todavia:

remontándose, en cambio, unos años más atrás, se conprenderá que lo ahora sucedido tiene la precisión inexorable de un silogismo: a ciertas premisas dadas siguió una conclusión previsible. João Goulart - y con él el Brasil entero - recogió, en amargura, los frutos que, en dulcedumbre, había sembrado Juscelino Kubistchek. Y de ese modo resultó que - pese a cuantos quieran pintar al Brasil como el país de los imponderables por excelencia - también allí dos más dos siguen siendo cuatro, igual que en cualquier otra parte del mundo... (IDEM).

Toda a sustentação analítica do fato restará embasada nesse enunciado, no qual a administração de Juscelino Kubistchek surge como origem de um processo sobre o qual é evocada a poderosa referência silogística como marca de universalidade. É fundamental notar que em um mundo referencial consolidado para um público argentino de formação superior ou similar, a figura e a administração de Juscelino Kubitschek, em sua herança varguista, encontram-se muito diretamente associadas, por analogia, à figura e ao governo interrompido de Arturo Frondizi (1958-1962), da UCRI, inclusive em suas relações de aproximação com o peronismo. A sustentar a operação analógica desse quadro de 
referência, tem-se o desenvolvimentismo industrialista como política econômica daqueles governos e seus desdobramentos - positivos para alguns, negativos para outros - na cisão política reinante em ambos os países. Poder-se-ia talvez afirmar que o jornalista argentino, referindo-se a Kubistchek sob tal enquadramento na construção da notícia internacional, está a apontar muito diretamente para um mundo referencial de significação disponível ao leitor argentino no qual se põe claramente o frondizismo.

Dentro de um tal "mundo possível" constituído na narrativa noticiosa, a figura e a imagem do governo deposto de João Goulart aparecem simplesmente como uma espécie de fator de aceleração ou precipitação de uma crise cujos elementos condicionantes já estariam dispostos anteriormente, a partir dos supostos desdobramentos negativos do desenvolvimentismo de JK. A racionalização assim disposta tornava de menor importância para o desfecho golpista o "esquerdismo", o "populismo" e a suposta ausência de "planificação realista" do governo caído, elementos que costumavam ocupar posição decisiva em mundos possíveis concorrentes. Todavia, a notícia não deixava de explicitar tais elementos imediatos na construção do sentido do golpe de Estado no país vizinho:

Goulart demostró ser un astuto político en materia de cabildeos y maniobras de poco alcance: tal como la manera que se liberó del régimen parlamentario que lo tenía manietado (...). Politicamente, su posición fue tan equívoca como lo había sido la de su predecesor: más que equívoca, irresoluta. Cuanto más hábil se mostró, al comienzo, para maniobrar en el campo de sus adversarios, tanto menos lo fue para imponerse luego en el de sus aparientes aliados. (...) La manera como se debatió entre las crecientes exigencias de su entourage extremista y las que le planteaban la realidad económica del país, es índice de lo poco planificada que fue su acción (IDEM, p. 33).

E assim pode-se compor o acontecimento do golpe constituindo uma rede articulada de "fatos", nos termos da aqui chamada operação de verificação no discurso jornalístico:

Mientras "Jango" anunciaba grandilocuentemente las 'reformas de base', regulamentava las inversiones extranjeras, decretaba una innocua reforma agraria, aumentaba al doble los salarios mínimos, expropiaba refinerías de petróleo privadas y pedía reformas constitucionales para favorecer a los comunistas, el pueblo lo hostigaba con crecientes muestras de descontento y de falta total de apoyo: se producía la huelga de los marítimos en Río, la ocupacíón de tierras por parte de los campesinos de Paraíba, la huelga de 
servicios públicos en Guanabara, la de telegrafistas en todo el país, la invasión del despacho presidencial por parte de campesinos y obreros hambrientos, mientras otros, que estaban desocupados, acampaban frente a Larangeiras (IDEM, p. 33).

Assim, apesar de posto apenas como a cena final de um processo de crise supostamente mais profundo e duradouro, a imagem recorrente de "caos social" associada à suposta inépcia do governo Goulart, reproduzida em variados órgãos da imprensa informativa brasileira e internacional, bem como no material de várias agências noticiosas, não deixava de se fazer presente em Panorama como matéria-prima de sentido em um mundo possível no qual se punha o golpe.

No que toca especificamente à intervenção militar no processo político, a notícia a enquadra como "el golpe de gracia al discípulo de Vargas" (IDEM, p. 34), de forma coerente com o conjunto da construção discursiva. Nesse sentido, três ordens de elementos são apontadas como motivadores da intervenção:

\begin{abstract}
En este conflicto [Governo x Forças Armadas] hubo, sin duda, elementos ideales: una consciente actitud de parte de los militares de impedir que el país se desbarrancace y que quedase abierta la puerta para una total conmoción social. Importante fue también (...) el delicado problema de la disciplina castrense. Pero también pesaron razones no despreciables de índole económico-social: el ejército en el Brasil está mal pagado y, sobretodo, la suboficialidad y la tropa sufren la precaria situación del país en el pleno rigor, junto con los demás setores de la población (IDEM, p. 34).
\end{abstract}

Desses três fatores, o último é destacado na notícia, quando se aponta para o fato segundo o qual "en julio del año pasado fueron precisamente los oficiales 'gorilas' y conservadores los que hicieron a Goulart un severísimo planteamiento acerca de aumentos de sueldo para 'contener la ira de las tropas hambrientas y mal pagadas'. E complementa: "por ello (...) cabe tener más de una reserva con el curso que darán a la política económica del país los círculos militares que ahora han provocado el cambio de poder" (IDEM, p. 34).

Assim, esse mundo possível, no qual o golpe de Estado ganhava sentido, comportava uma dúvida essencial quanto ao futuro: teriam os militares um projeto para o 
país, embasado em uma política econômica "adequada" ou a intervenção teria como fruto uma nova improvisação nacional destinada a atender reclamos corporativos/conservadores imediatistas e "irracionais"? Predominariam no futuro as idiossincrasias nacionais ou se implantariam processos administrativos para uma reconstrução do país segundo lógicas supostamente universais? Poder-se-ia dizer: tratavase de fato de uma "Revolução", na qual a Argentina pudesse de algum modo inspirar-se, ou se estaria diante de uma quartelada à brasileira? Como se verá adiante, tal questão passará a orientar as operações ideológicas na construção da visão jornalística argentina acerca da ordem autoritária em implantação no Brasil.

O acontecimento do golpe no país vizinho tem igualmente sua trama de sentido elaborada em referência ao campo internacional. Panorama destaca três países nesse campo cujos interesses, associados ao respaldo ou a resistências internas que suscitam, teriam influenciado no desfecho da crise brasileira: Estados Unidos, URSS e Cuba.

No que toca ao primeiro, a notícia informa ser muito provável ter havido uma interferência direta, até mesmo pela "estreita relação" que se supõe existir entre os militares brasileiros e seus colegas do Pentágono (Idem, p.34). Para além dessa articulação posta como imediata, Washington teria vultosos interesses econômicos e financeiros a defender no Brasil e, sobretudo, seria inaceitável para os Estados Unidos o risco de uma nova e gigantesca Cuba na América do Sul. Assim, pode-se concluir que "Estados Unidos no temiera los planes de João Goulart, sino los resultados imprevisibles de su falta de planes" (Idem, p. 34). As lógicas, os pressupostos e valores do mundo referencial da Guerra Fria reforçavam assim a verossimilhança de uma quase "inevitabilidade" da ruptura institucional no Brasil.

Nessa direção, informa-se que a aproximação Brasil-URSS durante o governo Goulart não havia prosperado significativamente, não obstante as iniciativas pontuais de ambos os governos e a atenção "especial” de Moscou na evolução da política brasileira. Algo que teria ocorrido em função de que "consabidamente, [Moscou] no se compromete sino con situaciones más o menos definidas o estables" (Idem, p. 35). Seguindo-se à 
remissão ao mundo referencial da ordem bipolar, tem-se, finalmente, as possibilidades de penetração no Brasil - e na Argentina? - do que é chamado de o "outro comunismo", isto é, aquele de Cuba e de Castro, "con sus conexiones latinoamericanas y quizás asiáticas” (Idem, p. 35). Quanto ao "castrismo", o texto noticioso se alonga e adota tom mais analítico:

\begin{abstract}
tiene en Brasil el terreno demasiado bien abonado como para tener necesidad de obrar por medio de agentes extranjeros ni de echar mano de conspiraciones diabólicas. Cada campesino pauperizado en el Nordeste, cada obrero de fábrica cuyo salário real se há ido deteriorando sistemáticamente desde hace muchos años, puede ser excelente agente del comunismo castrista. Goulart no hizo nada para reprimir sus manifestaciones políticas y hasta favoreció la reunión en Niteroi en 1963 y la más reciente del CUTAL en Brasília (IDEM, p. 35).
\end{abstract}

Operando com a verificação dos "fatos" relativos às reuniões de Niterói e de Brasília, a notícia, sempre nos quadros referenciais da Guerra Fria e do anticomunismo, reconstitui proposição recorrente na imprensa informativa do período, segundo a qual o golpe reagira a uma dupla ineficiência de Goulart. De um lado, a ausência da repressão "devida" às movimentações políticas "comunistas" e, de outro, a sempre enfatizada incapacidade para atacar, de forma "consequente" e "planificada", vale dizer, dentro da ordem capitalista como mundo referencial, os "verdadeiros" e "profundos" problemas sociais e econômicos do país.

É assim que a narrativa noticiosa pode ser concluída, com rigorosa verossimilhança do mundo possível que constitui, articulando "fatos" sob as lógicas de mundos referenciais potencialmente compartilhados com os leitores:

Goulart, el hábil titiritero en los ambientes parlamentarios y de gabinete, terminó por ahogarse en una situación económica y social, para salir de la cual y hacer salir de ella al país le faltaron conocimiento, energía y asesores. Las circunstancias en que esta catástrofe final se produjo son puramente enecdóticas, dado que la situación en sí había comenzado mucho antes (IDEM, p. 35).

E, quanto ao futuro que se descortina após o acontecimento do golpe: 
Las perspectivas que se abren ahora al Brasil no están condicionadas (...) por los hombres que se estén moviendo dentro de esta atmósfera circunstancial o anecdótica: llámense Amaury Kruel, Castelo Branco, Carlos Lacerda o Adhemar de Barros. Importa, en cambio, saber si cualquiera de ellos o algún otro sabrá atacar el mal de raiz del Brasil - la inestabilidad económicofinanciera - como no supieron o no pudieron ya acerlo ni Janio Quadros ni João Goulart (IDEM, p. 35).

Fica assim colocada sob o condicionamento de tal questão, quanto aos destinos da ordem pós golpe, a avaliação francamente positiva de Panorama quanto ao acontecimento que notícia. Desse modo:

La caída [de Goulart] es (...) sin duda un síntoma positivo. Demuestra (...) que en el Brasil impera, después de todo y pese a las aparencias contrarias, una lógica. Es de esperar que ese imperio se mantenga y que lo que acaba de terminar implique el cierre de un largo capítulo de la história brasileña (IDEM, p. 35).

Sendo assim, dependendo do quanto pesassem no futuro as singularidades nacionais brasileiras frente a uma lógica política e econômica de validade supostamente universal, a ruptura institucional no Brasil poderia, ou não, representar um caminho possível para uma solução da crise argentina.

Nesse sentido, em uma primeira notícia acerca da política econômica da nova ordem, é possível ver uma avaliação francamente positiva desta. O quadro positivo se desenvolve apelando a um mundo de referência no qual se situam os conceitos e pressupostos de um liberalismo ortodoxo, constituindo-se assim como elemento central de verossimilhança.

As peculiaridades nacionais brasileiras quanto a tal área da vida nacional são destacadas inicialmente como um contraponto às ações "corretas" do governo "revolucionário". Nesse sentido, "informa-se" ao público leitor de Panorama:

En los ambientes especializados de todo el mundo, Brasil goza de la incómoda reputación de ser el 'continente perdido' de la economia. Ignorando todas las leyes conocidas, parecería que su inflación no respecta límites (oscila entre un 40 y un 80 por ciento anual), su deuda exterior, ya famosa, há alcanzado la astronómica cifra de tres mil millones de dólares, y la mecánica de su proceso 
parece basarse em cuatro princípios esenciales: $1^{\circ}$ : Dios es brasileño; $2^{\circ}$ : con confianza todo se arregla; $3^{\circ}$ : el dinero se hace con papel, y $4^{\circ}$ : 'los americanos nos van a ayudar' (PANORAMA. Ago 1964, p. 78).

Frente ao quadro referencial mencionado, a situação pré-golpe do que é definido como "economia" apresenta traços caóticos, em função de uma assim posta peculiaridade brasileira - com a marca da "irracionalidade" em cada um de seus quatro "princípios" -, inclusive com a verificação de índices numéricos que sempre apontam para "fatos" no discurso jornalístico.

A notícia informa, todavia, que tal situação passaria a ter mudado no Brasil de forma gradual em virtude de que "Humberto Castello Branco, que há desplazado en el poder al gobierno izquierdista de Goulart, há decidido poner orden de una vez por todas en ese caos económico que es Brasil" (IDEM). O homem-chave desses novos rumos, segundo a narrativa noticiosa, ou personagem central de uma nova trama, é o Ministro do Planejamento, Roberto de Oliveira Campos, assim apresentado ao público argentino: "brillante economista y diplomático, de 47 años, que fue embajador brasileño ante Estados Unidos hasta diciembre del año pasado, cuando dejó el cargo por no estar de acuerdo con la política de Goulart” (IDEM). No quadro referencial do liberalismo, impossível melhor apresentação, não apenas por ser aberta com o adjetivo "brilhante".

O texto de fato faz de Campos a base individual do exame positivo da política econômica "revolucionária", à medida que este "conoce muy bien la magnitud de la tarea que le espera" e que "es demasiado consciente como para soñar en transformar la economía de un día para otro" (IDEM). Frisam-se ainda os fatos segundo os quais durante o governo Goulart o valor do cruzeiro caíra $83 \%$, o custo de vida aumentara $370 \%$, enquanto os investimentos estrangeiros despencaram de 85,1 milhões de dólares para 4,5 milhões. Segundo a notícia, os primeiros objetivos do ministro seriam a redução em 70\% no índice de crescimento inflacionário ainda em 1964 e outra igualmente drástica no déficit fiscal.

Referenciada na ortodoxia liberal monetarista, a notícia qualifica os atos do novo regime como "un enérgico comienzo" (IDEM). Nessa direção, a matéria compõe um 
quadro impressionante de medidas "positivas". Dentre essas, contam-se o cancelamento de 200 milhões de dólares anuais de subsídios ao trigo e ao petróleo, o projeto de criação do Conselho Monetário Nacional, a revisão do crédito comercial à indústria, o cancelamento do aumento de $100 \%$ do salário mínimo, decretado por Goulart, bem como a criação de mecanismos "adequados" de financiamento às exportações.

O centro de tal quadro é ocupado, entretanto, por uma medida legal de caráter tributário, talvez incongruente com a ortodoxia referencial, qualificada como “emergencial". A nova lei de impostos, remetida "imperativamente al Congreso" (IDEM), visava eliminar o déficit fiscal ainda em 1964, aumentando a arrecadação em 500 milhões de dólares. O espírito da medida seria a correção inflacionária dos valores devidos pelas empresas em 90 dias. Além do que o governo esperava cobrar, no período, 23 milhões de dólares em impostos atrasados. Tais fatos verificados em números, tornados acontecimentos pelos quadros referenciais acima aludidos, compunham um mundo possível plenamente veraz que constituía o princípio de uma nova ordem econômica em implantação no país vizinho, para além das idiossincrasias nacionais deste.

Impressiona como se dá voz ao então Ministro da Guerra, Artur da Costa e Silva, no que toca ao processo de correção monetária das dívidas tributárias das empresas e cobrança de impostos atrasados destas. Segundo se noticia, a mensagem fora transmitida pelo general brasileiro em rede de televisão: "conviene pagar ahora caballeros (...) porque si no tendremos que ir cobrarlo nosotros. Mucho le deben Uds. a la revolución y ahora es el Estado que necesita dinero" (IDEM). Não é preciso nenhum esforço interpretativo para notar o elogio ao tom direto e autoritário ("revolucionário"?) da cobrança militar ao empresariado, associada à racionalidade suposta das medidas econômicas. Ainda mais que a veracidade do quadro traçado exigia o reconhecimento de que "muchos brasileños claman desesperados ante las rigurosas medidas adoptadas por el gobierno" (IDEM).

Com o combate "rigoroso" à inflação e ao déficit fiscal, viria mais um canal de saída a longo prazo da crise econômica tornada crônica: os investimentos estrangeiros. Quanto a esse ponto essencial para a narrativa, lê-se: “en lo que respecta a los inversores 
extranjeros, se han puesto a desempolvar febrilmente todos los proyectos de expansión puestos a dormir en la época de Goulart" (IDEM). E se segue uma impressionante lista de projetos “desempoeirados":

\begin{abstract}
Willys Overland do Brasil, el mayor fabricante de automóviles del país, tiene en vista ya una radicación de 30 millones de dólares; Volkswagen porá 21 millones de dólares más en su fábrica de San Pablo; Bunge y Born de la Argentina construirá una planta de superfosfatos por valor de 16 millones; Columbia Ribbon \& Carbon há declarado que colocará ocho millones más y la famosa casa Philips de Holanda levantará una fábrica de tubos de televisión estimada en 10 millones de dólares (IDEM).
\end{abstract}

Informa-se ainda ao leitor argentino que somente no último mês, 35 grandes empresas estadunidenses teriam enviado seus executivos a São Paulo para prospectar o mercado brasileiro e, ainda, que seis dos maiores empresários brasileiros haviam sido convidados pelo banqueiro David Rockfeller para uma reunião em Nova Iorque, na qual se discutiriam possibilidades de investimento em mais de 100 setores da economia brasileira. A "Revolução" brasileira parecia assim começar a representar exemplo para a crise argentina nas páginas de Panorama, no interior de uma narrativa noticiosa na qual medidas "corretas" e eficazes por parte do Estado tornavam sem sentido a oposição entre agrarismo e industrialismo, argumento importante do mundo possível que assim se constituía e se projetava no futuro.

Nesse sentido, dá-se voz direta a Castello Branco, que aparece afirmando, como fecho narrativo: "sólo creando una auténtica prosperidad (...) podremos distribuirla equitativamente entre los brasileños" (IDEM).

Entretanto, se, nesse nível da garantia de eficácia de medidas "racionais" e "necessárias" no plano econômico, um certo grau de autoritarismo se torna compatível com o mundo referencial do discurso, intervenções autoritárias para implantação de medidas "irracionais" e, portanto, ineficazes, em setores inadequados da vida social, começam a ser vistas como um risco para os rumos futuros da "revolução". É com a utilização do recurso da ironia e da graça que Panorama constrói como notícia uma 
possível advertência contra uma tal degeneração autoritária. Trata-se de notícia acerca do trânsito de automóveis no Rio de Janeiro e de medidas "revolucionárias" para resolver seus problemas:

\begin{abstract}
Para hacerce una idea de la magnitud del problema de estacionamiento en Rio de Janeiro, el lector deberia imaginar lo que sucedería si todos los empleados de Buenos Aires tuvieran auto y lo usaran para ir todos los días a su trabajo. Como en Rio no hay playas de estacionamiento, ni garajes, ni espacios reservados en la calle, que basten para semejante horda de coches, y como los agentes de tránsito son muy benévolos con las debilidades ajenas, los cariocas estacionan en cualquier parte, en fila simple, o doble, o triple, en las veredas, en las esquinas, en los refugios o donde sea: en cualquier parte menos encima de otro coche. El gobierno revolucionario, dispuesto a poner las cosas en su lugar, en todos los órdenes, decidió tomar cartas en el asunto, para lo que designó Director de Tránsito al coronel Américo Fontenele, de la Fuerza Aérea (PANORAMA, out, 1964, p. 93).
\end{abstract}

O termo "revolução" surge aqui em um cenário cotidiano, não diretamente associado às "grandes questões" nacionais, sofrendo um deslocamento semântico, ou de mundo referencial, que lhe emprestará sinais de inadequação, quase despropósito, expressos em efeito de humor irônico. Novamente tem-se evocada uma idiossincrasia nacional, posta nos motoristas cariocas, no caos de carros estacionados em toda parte e na fiscalização "benévola". E a "revolução" surge para intervir nessa instância da vida porque pretende colocar "ordem" em literalmente "tudo". A extrapolação fora de propósito não precisa ser explicitada e ainda ganha tom definitivamente cômico quando se convoca para resolver um problema de trânsito perfeitamente "terrestre" a um coronel da Força...Aérea.

A matéria segue, em tom quase cômico, noticiando as ações do coronel Fontenele para impor ordem ao trânsito carioca. Primeiramente, faz-se referência a uma frota de carros guincho contratada pelo poder público para remoção de carros mal estacionados. Estes logo superlotaram os depósitos da polícia e o coronel, com "santa indignación" (Idem), ordenou que os carros fossem levados a ruas suburbanas e lá deixados, evidentemente que "estacionados como corresponde" (Idem). Obviamente, perdeu-se completamente o controle sobre o paradeiro dos carros "abandonados", cujos proprietários passavam a enfrentar verdadeiro "calvario" para reavê-los, muitas vezes 
encontrando seus patrimônios completamente saqueados. Fato: "un capitán del Ejército tardó cuatro días para encontrar su Volkswagen, y pudo darse por satisfecho con encontrarlo en buenas condiciones porque tras las grúas de la policía suele marchar una pandilla de saqueadores que en poco tiempo no dejan otra cosa que la carrocería pelada" (IDEM).

O autoritarismo "irracional" ("revolucionário"?), por uma via quase puramente repressiva, gerou no quadro discursivo composto na notícia não uma solução razoável do problema original, mas sim problemas adicionais. Ainda, para complicar o quadro, o "infatigable" (IDEM) coronel, ao perceber que a imensa maioria dos carros mal estacionados escapavam da remoção em função da impossibilidade de o poder público contar com carros guincho em quantidade suficiente, ordenou que os agentes passassem a esvaziar os pneus dos carros em situação infracional. Como verificação, a matéria apresenta foto de agentes policiais esvaziando os pneus de uma longa fila de carros. Toda a imprensa carioca, segundo se noticia, considerou a medida atos de "vandalismo" (IDEM). E, "a pesar de que muchos jurisconsultos manifestaron que la disposición era contraria a todas las normas del derecho, el coronel declaro que 'la campaña continuaría hasta que los conductores se decidieran a colaborar con las autoridades"(IDEM). E segue a narrativa do irracionalismo autoritário, em tom mais decididamente jocoso, usando referências a "fatos" que, assim enquadrados, transformavam-se em "acontecimentos":

Entre las primeras víctimas de los 'desinflamientos' cayeron el embajador de Gahna, tres diputados nacionales, un membro de la asemblea estadual y un detective de civil que seguía a un sospechoso. Una patrulla que había desinflado alegremente las gomas de 32 coches estacionados, advirtió, lamentablemente tarde, que estaban bien estacionados (IDEM).

A ação autoritária, cega a convenções hierárquicas arraigadas e muito próxima do simples erro, gerou igualmente conflito ao chocar-se com reações de mesma índole:

Cuando otra unidad 'depresionista' intentó 'bajar' unos tantos vehículos oficiales en infración, fue alejada violentamente por un pelotón de infantería de marina con bayoneta calada, y varios infantes provistos de ametralladoras de 
mano se colocaron de guardia junto a los autos para prevenir toda nueva tentativa de agresión (IDEM).

Ou seja, as medidas autoritárias, com o objetivo elogiável de colocar ordem no caos do trânsito carioca, estavam estabelecendo um caos social agravado, não restando nem perto de atingir sua boa intenção original. Com destaque de duas páginas, em matéria com foto, a notícia representa uma advertência típica contra os riscos de uma degeneração autoritária no processo "revolucionário" brasileiro, como possível espelho para a Argentina.

A notícia informa que o coronel Fontenelle não estaria levando em conta as fortes críticas que se levantavam contra sua atuação, mas, ao contrário, julgava que a situação no trânsito do Rio estava melhorando significativamente, em nova evocação de uma "cegueira" autoritária. Assim, a narrativa noticiosa pode concluir ironicamente que "en los últimos tiempos se ha prohibido el estacionamiento en casi todas las calles céntricas, y a corto plazo los cariocas se verán obligados a guardar sus autos poco menos que en la heladera, con el consiguiente deterioro de los cromados" (IDEM, pp. 93-94).

O texto noticioso trata ainda de contrapor o irracionalismo imediatista das ações do coronel, em uma evocação simbólica potencial da Revolução como um todo àquela que se coloca como um planejamento de médio e longo prazo para enfrentar o problema urbano carioca, qual seja, "fomentar el uso de los transportes públicos” (Idem, p. 94). Aqui, em contraste com as questões macroeconômicas, a repressão pura e simples dos infratores representou o oposto de uma solução razoável. Cabe inferir a questão subjacente: onde mais a Revolução poderia representar inadequação semelhante ao extrapolar poderes de viés autoritário?

No final do ano de 1964, Panorama publica uma extensa fotorreportagem sobre o Brasil, certamente motivada pelo interesse jornalístico no país vizinho em virtude do golpe e da nova ordem que ali se instaurava. Na página inicial - que tem o fundo inteiramente ocupado por uma foto da praia de Botafogo, no Rio de Janeiro, com vista para o Pão de Açúcar, sendo observada por um menino negro, bastante magro, em pé - 
coloca-se a manchete, encimada pela palavra "Brasil", cujas letras garrafais alternam em altura, dando a impressão de movimento dançante. Uma evocação quase óbvia a um mundo referencial em que se plasmavam imagens recorrentes acerca do país vizinho (PANORAMA, dez 1964, p. 52). A manchete principal é "La Aventura de Crecer" (IDEM), que pode remeter a mundos referenciais distintos: crescimento econômico ou saída da infância, ambos marcados pelas incertezas de uma "aventura". Como sub-manchete, lêse "Un Caleidoscopio con Cristales de Aumento: el Vecino Más Importante y Menos Comprensible para Los Argentinos" (Idem). A diferença marcada pelo "mistério", no caso ancorado em um quadro referencial em que se situa o "exótico"; a proximidade calcada na "importância", que inequivocamente evoca poder. O tom geral do texto está dado. Um vizinho gigantesco, estranho, com imensos problemas "de infância" a superar, com uma nova ordem, sem dúvida autoritária, em processo de implantação. Tudo sob o olhar argentino.

Nessa direção, o impacto inicial no leitor é buscado por uma narrativa de corte literário na qual se traçará o retrato de um problema nacional brasileiro, o qual remetia a um mundo referencial, consagrado em variadas fontes de produção de significado, acerca da pobreza endêmica no país - o Nordeste:

\footnotetext{
Blanco, pegajoso, sólido, se desplomaba el sol sobre aquella tierra resquebrajada. Rumiando una plegaria, grupos de campesinos sonolentos se movían como muñecos trágicos sobre los cultivos quemados, sobre las espinas de los matorrales ariscos, sobre cadáveres de caballos huesudos, que murieron de sed y de hambre revolcándose en el polvo del sertão. Y también ellos morirían, si no aparecía una nube, muchas nubes, muchas gotas frescas y dulces para calmar la garganta áspera de los hombres, de las bestias, de la tierra. En el interior de Pernambuco, en Ceará, en Piauí, se formaron procesiones patéticas de campesinos con cirios e imágines, (...) desgraniando oraciones. El Nordeste brasileño clamaba a los cielos por agua. Y los cielos escucharon (IDEM).
}

A “ação divina" em atenção às preces dos camponeses nordestinos famintos, em trágica ironia, vem sob a forma das enchentes de junho e julho de 1964, o "fato" que desastrosamente contrasta com a narrativa da seca: 
Hubo un trueno, después otro, y el 6 de junio se largó a llover, siguió lloviendo toda la semana, todo el mes, todo julio. Ríos de los que nadie se acordaba renacieron, se convertieron en torrentes, salieron de cauce y una correntada irresistible barrió las llanuras, arrancó los puentes, invadió las ciudades. Los pocos animales que habían sobrevivido a la sequía nadaban frenéticos antes de perecer bajo un líquido arremolinado y pardusco. Se evacuaron las poblaciones, se sacó a los enfermos de los hospitales, se trasladó a los presos de las cárceles. Ciento cincuenta mil personas quedaron sin hogar. Se clausuró la carretera 'Br-11' (sic), que alimenta todo el tránsito terrestre de la región.

E seguem os acontecimentos e números verificadores dos fatos trágicos:

El 75 por ciento de la cosecha de porotos, casi todos los sembradíos de trigo (sic), resultaron destruidos por la corriente. Los yacimientos de sal - principal fuente de trabajo para cien villas nordestinas - se inutilizaron y Brasil deberá importar sal el año que viene. Muchas personas se ahogaron sin poder llegar a los terrenos altos. Los que consiguieron refugiarse sonrieron, seguros, pero en los campos de evacuación brotaron pestes y la muerte continuó. Entonces dejó de llover. Y el sol volvió a desplomarse blanco, sólido, sobre una tierra en ruinas (IDEM).

O Nordeste brasileiro, uma vez mais representado como uma terra em que as tragédias se sucedem, é explicitamente posto como um cenário representativo dos problemas e características nacionais brasileiras, quando a narrativa de fundo é interrompida na leitura por uma página quase inteiramente tomada por foto panorâmica do centro histórico do Rio de Janeiro contrastando com os grandes prédios do centro moderno da cidade. Acima da grande foto, lê-se: "en Brasil, el clima es tan extremista como la história y la arquitectura, como los dirigentes y la geografia” (IDEM, p. 53).

A página seguinte ainda se oferece ao leitor como um grande hipertexto da narrativa principal. Ali se tem duas grandes fotos, tomando a metade inferior e parte da metade superior da página, respectivamente. A primeira, focando panoramicamente a avenida paulista, ladeada por grandes arranha-céus, em uma São Paulo ao anoitecer; a segunda, uma mulher jovem, de biquini, tomando sol nas areias de uma praia. Na legenda da primeira, tem-se: "al anochecer, el corazón de San Pablo se enciende en una miríade de luces multicolores que reflejan el progreso del coloso brasileño", enquanto que na 
segunda, lê-se: "las arenas de Copacabana contemplan indiferentes los hermosos cuerpos femeninos que despliegan sus tentadoras formas a la carícia del ardiente sol carioca" (IDEM, p. 54).

Desse modo, narrativa de fundo e enormes hipertextos imagéticos vão compondo o mundo possível de um país marcado por contrastes quase inexplicáveis para olhares estrangeiros e por "extremos" que, analogamente ao clima, aparecem marcando toda a vida nacional. Exatamente nesse sentido a narrativa de fundo é retomada:

Es que los nordestinos en Brasil ya hace siglos que son la tragedia y la encarnan en la forma en que se dá todo dentro de este país fascinante: hasta el extremo, en una sucesión de contrastes vivísimos y dramáticos. El clima es extremista en Brasil, igual que la história, igual que la geografia, igual que los planes económicos, la arquitectura, las aguamarinas, las diversiones, las batallas parlamentarias (IDEM, P. 55. GRIFO NO ORIGINAL).

A essa noção de "extremos", como marca de variadas faces da nacionalidade brasileira, soma-se a noção de gigantismo, frequente em diversos mundos referenciais representativos daquela nacionalidade. $\mathrm{O}$ elemento escolhido para simbolizar o gigantismo brasileiro é bastante recorrente: Brasília. A construção da nova capital brasileira, suposto marco da ocupação recente do interior do país, que impactara de diversos modos muitas franjas do público leitor argentino, é retomada no texto de fundo:

\footnotetext{
Kubitschek desempolvó un proyecto discutido a lo largo de 170 años; convocó a un ejército de diseñadores, de urbanistas, de arquitectos; estudiaron planos, sacaron fotografías, debatieron las cosas a la brasileña y nació Brasília. Carreteras sin cruces, autopistas ligeras, vias férreas directas, mucha luz, toneladas de sol, oceános de aire libre. Palacios, torres, templos de líneas tan revolucionarias que el visitante cree allarse en otro planeta (IDEM, P. 55. GRIFO NO ORIGINAL).
}

Fruto de um debate "à brasileira", que parece indicar inconsistência, o futurismo modernista da cidade assim descrito é imediatamente associado à imagem recorrente de uma suposta "desumanidade", que se mostra em distâncias imensas, intransponíveis a pé, impossibilidade de relações de vizinhança, ausência de cafés aprazíveis e de praças verdadeiramente acolhedoras. Em suma, "una ciudad anónima y monstruosa” (Idem). E 
o complemento essencial: "Brasília sufre de gigantismo. Y está bien. Brasília es Brasil" (IDEM).

O gigantismo da capital é imediatamente associado a um tão impressionante quanto recorrente painel de dados fáticos, símbolos de um Brasil Gigante em diversos mundos referenciais. A dimensão do rio Amazonas; 40.000 espécies de plantas; $12 \%$ das áreas florestais do planeta; exploração de ouro a 2.400 metros de profundidade; superfície de 8,5 milhões de quilômetros quadrados, igual a toda a Europa, quarta maior do planeta, “que impone también un tamaño para ver y un tamaño para desear" (IDEM); 70 milhões de habitantes, três vezes e meia a população argentina, com projeção de 168 milhões para o ano 2000; terras interiores “vastíssimas", nas quais "hay todavía selvas inexploradas por el hombre blanco, ochocientos mil indios que no han saído aún de la prehistoria, desiertos atroces, ríos, fieras, insectos y hasta tribus de canibales" (Idem). Diante do quadro até aqui traçado, pode-se asseverar:

Sencillamente no se puede juzgar a semejante país con criterios comunes, a riesgo de no entenderlo nunca. La exageración es un rasgo nacional, porque en Brasil las exageraciones se ven, se tocan y se viven a diário (IDEM).

É, pois, diante do desafio de estabelecer critérios especiais de julgamento para entender o país do "exagero", do "gigantismo", dos "extremos", e do Golpe de Estado, que a matéria trata de destacar, por vezes reiterar, símbolos e supostas características nacionais brasileiras. Nessa perspectiva se põe a favela carioca como símbolo sociocultural, o sentimento nacionalista no país e uma assim posta "agressividade" do seu “povo”. Quanto às favelas, assim se monta o discurso:

Después de contemplar desde los morros la beleza esplendente de Rio, no debe azorarnos que en las favelas haya hombres y mujeres misérrimos, capaces de padecer hambre un año enterro con tal de comprarse para carnaval un disfraz que cuesta 250.000 pesos argentinos. Y luego, por las calles, bailar hasta el delirio, hasta caer rendidos, hasta morir bailando. Muerte lógica, empero, para unos hombres y unas mujeres que en los otros once meses han chapoteado en la pobreza desmesurada de un país sin medidas. Porque en Brasil la favela no es (...) un problema de vivenda, es un problema de inanición. (...) Hermosas a 
la distancia, (...) feas cuando uno se acerca y mortales cuando se penetra en ellas, las favelas de Rio de Janeiro son un símbolo (IDEM).

Miséria endêmica e alegria carnavalesca como fuga curta e irracional, mais uma associação clássica de um mundo referencial em que se constitui a verossimilhança da narrativa jornalística, sobreposta ao estilo algo literário. Igualmente recorrente, mais uma vez, o contraste absolutamente verídico como mundo possível:

\begin{abstract}
A pocos metros de allí, en las joyerías y boutiques de la rua do Ouvidor, Buenos Aires o Gonçalves Dias, los restos de la aristocracía magnífica del imperio se encuentron con los formidables millonarios de la industria y la banca. La clase media, ese sufrido moderador de los conflitos sociales, prácticamente no existe en Brasil. No sería, después de todo, muy brasileña (IDEM. GRIFO NO ORIGINAL).
\end{abstract}

País de extremos, uma assim posta ausência da classe média no Brasil aponta para um contraste significativo com o disposto em um mundo referencial muito presente para certa franja de público letrado na Argentina, no qual o país platino aparece com sua ordem social justamente fundada em uma supostamente sólida, numerosa - e "sofrida" - classe média.

No que toca a um suposto sentimento nacionalista, que apresenta "o país" como sujeito difuso, este é caracterizado na forma de um temor ou prevenção supostamente característicos. Nesse sentido, “el Brasil (...) que se derrama por una superficie tan grande (...), de noche no duerme pensando que pueden venir los ladrones y robarle un pedazo de territorio" (Idem). A metáfora bem pode encontrar ressonância interpretativa em um mundo referencial no qual o Brasil aparece muito cioso na defesa de suas fronteiras após um passado de conflitos territoriais com vizinhos sul-americanos. A nova ordem no país, com os militares no núcleo do poder, será adiante associada a possibilidades futuras de conflitos internacionais graves em torno de questões territoriais.

Para além desse aspecto defensivo-militar, o nacionalismo brasileiro, segundo a narrativa, estaria, ao longo da história do país, criando uma "cultura" letrada e artística original em variados setores, além de manifestações típicas de caráter popular elevadas 
ao nível cultural. Quanto ao primeiro aspecto de uma "cultura brasileira", a matéria lembra o leitor argentino:

\begin{abstract}
Brasil se halla en sus contradicciones, sus cataclismos, sus crisis multiduninarias, pero con más justicia lo representan por igual la arquitectura fascinante de Oscar Niemeyer, las esculturas barrocas y exquisitas del 'Aleijadinho', las fantasias cromáticas del pintor Cândido Portinari, la poesía de Drummond de Andrade, el talento descriptivo del novelista Jorge Amado, la maciza fertilidad musical de Heitor Villalobos (IDEM).
\end{abstract}

No que toca ao segundo aspecto, relativo a uma "cultura popular":

\begin{abstract}
Ritmos hipnóticos forjados en las religiones negras de la 'macumba' carioca y del 'candomblé' bahiense, escindidos de su significado litúrgico en la euforia del carnaval, se han proyectado fuera de las fronteras y hoy las muchedumbres internacionales comienzan a admirar el espítitu desbordante del Brasil a través de sus composiciones populares, desde el samba y la marchinha hasta la bossa nova (IDEM).
\end{abstract}

Segundo a narrativa, ambos os estratos de produção cultural estariam operando no sentido de forjar e consolidar uma identidade nacional, sendo que "lo que se debe destacar es la conciencia que tienen los brasileños de estar gestando una cultura de acento original" (Idem). E que "no existe allá ese complejo de inferioridad ante las novedades de importación que frustra tantas iniciativas en la cultura latinoamericana” (IDEM). No mundo referencial em que se põe a questão da identidade cultural latino-americana, o Brasil ganha assim posição singular no discurso constitutivo da imagem apresentada ao público argentino.

Nessa direção, é destacada a ativa participação das “clases dirigentes” (IDEM) emprestando apoio material para artistas e literatos, "a pesar de que en el presente la mayoría de los escritores, poetas, plásticos y cineastas se orientan hacia formas de protesta casi subversivas" (Idem). Como índices de verificação são apontados os exemplos de mecenas brasileiros na área do teatro e a atuação do magnata jornalista Assis Chateaubriand e da família Matarazzo na consolidação do Museu de Arte Moderna de São Paulo. Assim, o retrato narrativo desse Brasil possível pode concluir: "Brasil crece 
porque en determinado momento sus hijos han aprendido a suspender las profundas disidencias que los separan y mirar todos juntos para la grandeza común" (Idem. Grifo no original). Impossível não ver aqui um contraste frente a um mundo referencial no qual a Argentina aparecia profundamente dividida, em todos os planos da vida nacional, entre peronismo e antiperonismo. Nesse mesmo sentido potencialmente contrastante, a narrativa reproduz uma imagem consagrada em certos círculos sociais argentinos acerca da unidade e da continuidade da ação internacional do Brasil:

Ejemplo rutilante de ese patriotismo es la diplomacia sutil del Itamarati (sic). Los brasileños hacen de las relaciones exteriores una tradición nacional y su cancillería es una de las más hábiles del mundo. Pues bien: el secreto que explica por qué há podido mantenerse através de los azares políticos es muy simple. Sus diplomáticos son todos de carrera, allá ser embajador o cónsul no es una prebenda partidaria sino una profesión. Y la estructura del Itamarati (...) sigue incólume mientras la tierra gira (IDEM).

Constituindo novo contraste no retrato "caleidoscópico" do país, a matéria aponta a "violência" como mais uma característica nacional brasileira, sob um enunciado muito potente na generalidade que constitui, segundo o qual, no Brasil, "cualquier cosa es normal si es violenta" (IDEM, p. 55). Assim:

\footnotetext{
Durante los campeonatos de fútbol interestaduales, vendedores ambulantes recorren las graderías en las canchas de Recife o de Fortaleza: junto con la naranjada y el pororó, la gente les compra los célebres faconcitos nordestinos 'para cuando acabe el partido'. Los diputados van con revólver y hasta con ametralladoras a las legislaturas, hay duelos entre las bancas, se matan. No en las sielvas de las lianas y de los árboles de caucho, sino en medio del paisaje marciano de los rascacielos, con fotografías en diarios que tiran millones de ejemplares, con transmisiones en cadena a través de 25 canales de televisión y 630 estaciones de rádio (IDEM).
}

Esse Brasil "agressivo" em sua modernidade parece ser o oposto do que se plasmava em mundos referenciais concorrentes, nos quais se punha uma índole pacífica do "povo" brasileiro. 
É, pois, sobre esse impressionante painel, retratando as singularidades nacionais brasileiras, todas de algum modo avessas a uma compreensão de tipo racional, que Panorama assenta a construção de sentido para o golpe de Estado, a ruptura institucional e seus possíveis desdobramentos futuros. Aqui o fio da meada do exame "racional" é retomado e se apresentam uma vez mais dados numéricos, de valor posto como universal, novamente para colocar a inflação, o custo de vida e o desequilíbrio fiscal como fatores supostamente determinantes da queda de Goulart. A comparação com a Argentina parece expressiva nesse sentido:

Tomando como base los precios de 1953, en agosto de 1961 - cuando renuncia Quadros a la presidencia de la república - la vida había subido unas seis veces. En igual lapso, en la Argentina el incremento de precios era de siete veces. Ya para deciembre de 1962 el costo de la vida en Brasil equivalía a diez veces los índices de 1953, superando ligeramente el ritmo de la inflación en la Argentina. La espiral se vuelve después vertiginosa y Goulart deja el poder este año con un promedio de precios veintéseis veces más altos que una década atrás. Para entonces, cálculos equivalentes de nuestro país solo denunciaban una suba de doce veces. Es decir, que si en 1953, un artículo costaba diez, ahora en la Argentina cuesta 120 y en Brasil 260 (IDEM, P. 61. GRIFO NO ORIGINAL).

Pelo que se pode depreender, até o final de 1962, segundo a narrativa, o processo inflacionário no Brasil seguia padrões regionais comparáveis aos da Argentina. A partir de 1963, contudo, os números brasileiros e a "realidade" que supostamente expressam entram em "vertigem", evocação renovada da imagem de caos e descontrole, sempre associada ao governo Goulart, como sentido "lógico" do golpe, conforme já referido. Seguindo a comparação: “claro que el pueblo brasileño, mientras estuvo en el poder João Goulart, probablemente sufrió menos que el argentino debido al mecanismo automático de salário móvil que regía y a la manga ancha del gobierno, siempre pronto a aceder en aumentos masivos en los sueldos" (Idem). Nos termos do mundo referencial que enquadra a narrativa, o resultado não poderia ser outro, senão a instauração da "vertigem" e o desfecho "inevitável": 
Es en 1963 cuando la tasa inflacionaria alcanzará la proporción nunca vista antes en la história de la humanidad: 80,6 por ciento [ao ano]. Ni Alemania después del tratado de Versalles experimentó algo parecido. (...) Semejante aventura financiera explicaría por qué los plutocratas de San Pablo pagaron el movimiento que derribó a un régimen que, sin embargo, era industrialista y desarrollista a su modo (IDEM. GRIFOS NO ORIGINal).

Tal sentido do golpe será colocado em perspectiva temporal alargada ao constituir-se como o resultado final da "história brasileira". Nesse sentido, são mobilizados elementos clássicos de uma historiografia de corte socioeconômico, segundo a qual se sucedem linearmente um Império, quando se consolidam os “barones del café", uma República Velha federalista, sob controle daquela oligarquia latifundiária e a ruptura modernizante de 1930. A figura de Getúlio Vargas é posta então como elemento central de um tal processo histórico brasileiro, até o desfecho de 1964, o que, para o leitor argentino, sem dúvida evocava a figura de Perón, embora a narrativa afirme que o político brasileiro se assemelhasse a "un caudillo argentino de los años 1830 ó 1840” (IDEM, p. $62)$.

Derrubado "pela direita" em 1945, retornando pela via eleitoral, faz um governo posto como "medíocre", cujas forças oposicionistas o conduzem à tragédia de 1954, "en una crisis que conmueve al país y al mundo" (Idem, p. 63). Importa perceber que a narrativa depositará, mais uma vez, a "culpa” original pelo desfecho de 1964 em dois "herdeiros de Vargas", isto é, de seu industrialismo desenvolvimentista fundado em apoio popular, com alianças à "esquerda", que produzira "irracionalidades" administrativas e atitudes sistematicamente demagógicas e "populistas": Kubistchek e Goulart, com o interregno de um sempre "incompreensível” Jânio Quadros, cuja figura é comparada a Groucho Marx, em uma evocação de inconsequência cômica indevida (Idem). Impossível não perceber em tal varguismo assim posto uma associação subjacente ao peronismo e seus aliados, como o frondizismo, proposta ao leitor argentino.

No tempo atual da notícia, punha-se o governo "revolucionário" de Castello Branco, cuja tarefa básica, segundo a narrativa que busca constituir o acontecimento, seria ordenar as finanças públicas e deter a "vertigem" inflacionária, usando, dentro de certos 
limites, o poder de tipo autoritário que a ruptura institucional lhe conferia. Dentro do mundo referencial a que se vem aludindo quanto a tal racionalização, a imagem do governo apresentada por Panorama ao público argentino, ao final de 1964, é, como se disse, francamente positiva.

Do ponto de vista político, o governo aparecia em tal imagem se equilibrando razoavelmente entre as oposições e o que é denominado "extrema direita", tendo em Castello Branco sua figura representativa central:

\begin{abstract}
Ahora le corresponde detener el alud a un mariscal bajito y gordo, de voz meliflua. Humberto de Alencar Castello Branco, político improvisado, há sabido ir sorteando con sorpreendente habilidad las críticas de los partidarios de Goulart y Kubitschek. Lo que es mérito mayor, puede ir conteniendo a los extremistas de la derecha, nucleados en la denominada 'línea dura de la revolución’: oficiales jóvenes que juegan un papel muy parecido al que encarnaron los sectores 'gorilas' en la Argentina (IDEM, p. 61).
\end{abstract}

A narrativa afasta desse modo a imagem que compõe do governo ditatorial brasileiro de um mundo referencial de ditaduras militares de "extrema direita" na América Latina, no qual a figura do militar "gorila" ocupa lugar proeminente. Ao mesmo tempo aponta, como já o fizera antes, para o risco de que o processo supostamente "degenerasse" para essa direção, isto é, de um autoritarismo movido por fatores "irracionais".

Do ponto de vista da política econômica, reitera-se o elogio à ortodoxia “necessária” conduzida pelos ministros Roberto Campos e Octávio de Bulhões, a qual "se inspira en la doctrina del FMI y suena muy parecido al que aqui represento Alvaro Alsogaray" (IDEM), economista e ex-ministro de Estado argentino, célebre no país por suas posições monetaristas ortodoxas.

Restava, assim, antever um possível porvir para a Revolução brasileira, pois "a Castello Branco y sus colaboradores el futuro se les presenta muy dudoso: Brasil, precisamente, no es la Argentina" (IDEM). Evoca-se mais uma vez a alteridade para construir o grande enunciado, subjacente à narrativa, segundo o qual as peculiaridades nacionais brasileiras poderiam conduzir o processo político do país a destinos 
imprevisíveis, ou singulares, soterrando seus elementos "racionais"/"universais", que poderiam ser, nessa medida, um espelho para o país platino. Sinais inquietantes dessa possibilidade já são apontados:

Políticos que hasta hace unos minutos apoyaban el régimen provisional, han pasado rápidamente a la oposición, en vista de las elecciones de 1966: el caso más notorio es el de Lacerda, gobernador de Guanabara, acérrimo antivarguista y catalogado como el 'golpista' por antonomasia, cuyo lenguaje tiene ahora un raro color de ‘integración’ (IDEM, p. 63).

A política posta como "tradicional”, com seus jogos auto-referenciados de sempre, aqui postos nas eleições de 1966, ameaçava a Revolução, fosse pelas "necessidades" repressivas que poderia desencadear ou pelo fracasso das medidas racionais que poderia determinar. Além do que

Las voces de protesta han comenzado a levantarse (...) contra el gobierno. Los pequenos industriales se quejan del aumento de las materias primas, los consumidores protestan por los crecientes precios de los productos de primera necesidad y los sindicatos reclaman aumentos en los salarios. Los brasileños no son lo que puede decirse un pueblo sacrificado: es más suscetible de criticar con esceptismo que de obedecer con disciplina (IDEM).

A "índole" popular/nacional brasileira era, portanto, mais um fator a se considerar em um possível fracasso futuro da Revolução. A possibilidade real de um tal fracasso é posta em termos muito expressivos, isto é, verazes para o público argentino, amarrando a narrativa jornalística:

Sí la revolución se viera perdida, probablemente el corpulento mariscal hallaría una fórmula absolutamente insólita - mandar tropas a alguna guerra, nacionalizar todos los latifundios, inventar el comunismo en el Nordeste - para salir del paso. (...) Claro, alrededor de Washington, en medio de cualquier país de Europa Occidental e inclusive en casi toda América Latina, tamaño viraje no es posible, porque conforma un atentado a la lógica. Pero Brasil no es lógico. Brasil es Brasil (IDEM).

Assim, o acontecimento do golpe e a ordem autoritária nascente no Brasil adquirem significado para o público leitor de Panorama. Em uma dupla direção: como possível ideologia de uma solução autoritária para a crise em ambos países no contexto 
de Guerra Fria e, assim, com validade potencial igualmente para a Argentina, nos elementos "racionais" que apresentava. Contudo, igualmente como acontecimento inserido em uma realidade nacional absolutamente singular em seu gigantismo e seus extremos, o que poderia conduzir a nova ordem de uma ditadura "irracional", em exacerbações autoritárias de toda ordem ou mesmo a um "fracasso" geral, com desdobramentos imprevisíveis e fora de qualquer lógica nos mundos referenciais disponíveis.

\section{Referências Bibliográficas}

ALSINA, Miquel. A Construção da Notícia. Petrópolis: Vozes, 2009.

CANTIS, Mario S. La Caída de los Tres Gobiernos Radicales. Buenos Aires: Centro de Estudios Unión para la Nueva Mayoría, 1995.

CAVAROZZI, M., Autoritarismo y Democracia (1955 - 2006). Buenos Aires: Ariel, 2009.

CHAlABY, J. O Jornalismo Como Invenção Anglo-Americana. Comparação entre o Desenvolvimento do Jornalismo Francês e Anglo-Americano (1830-1920). Rio de Janeiro: Mídia \& Jornalismo, 3V, 2003.

DE RIZ, Liliana, La Política en Suspenso 1966/1976, Buenos Aires: Paidós, 2000.

DONGHI, T.H., La Democracia de Masas. Buenos Aires: Paidós, 2000.

GAMBINI, H. Historia del Peronismo. La Violencia (1956-1983). Buenos Aires: Vergara, 2008.

HABERMAS, J. Mudança Estrutural da Esfera Pública. Investigações Sobre Uma Categoria da Sociedade Burguesa. São Paulo: Ed. UNESP, 2014.

HALL, Stuart. “A Redescoberta da 'Ideologia': o Retorno do Recalcado nos Estudos de Mídia”. In: RIBEIRO, Ana Paula G. e SACRAMENTO, Igor (orgs.). Mikhail Bakhtin. Linguagem, Cultura e Mídia. São Carlos: Pedro \& João Ed., 2010.

LLAIRÓ, Maria de Monserrat (comp.). El Gobierno de Arturo Illia y la Restauración Institucional. Las Relaciones Económicas Internacionales y la Crisis de Gobernabilidad (1963-1966). Buenos Aires: Ediciones Cooperativas, 2007. 
O’DONNELL, G.,Contrapuntos. Ensayos Escogidos sobre Autoritarismo y Democratización. Buenos Aires: Paidós, 2004.

PANDOLFI, Rodolfo e GIBAJA, Emilio. La Democracia Derrotada. Arturo Illia y su Época. Buenos Aires: Lumiere, 2008.

PARADISO, J., Um Lugar no Mundo. A Argentina e a Busca de Identidade Nacional. Rio de Janeiro: Civilização Brasileira, 2005.

POTASH, R. A., El Ejercito y la Política en la Argentina 1962-1973. De la Caída de Frondizi a la Restauración Peronista Primera Parte, 1962-1966. Buenos Aires: Ed. Sudamericana, 1994.

ROMERO, L. A. Breve Historia Contemporánea de la Argentina. Buenos Aires: Fondo de Cultura Económica, 2001.

ROUQUIE, A., Autoritarismos y Democracia. Estudios de Política Argentina. Buenos Aires: EDICIAL, 1994.

SÁNCHEZ, Pedro. La Presidencia de Illia. Buenos Aires: Centro Editor de América Latina, 1983.

SCARZANELLA, Eugenia. "Entre dos Exilios: Cesare Civita, un Editor Italiano en Buenos Aires, desde la Guerra Mundial Hasta la Dictadura Militar (1941-1976). Revista de Indias, vol. LXIX, núm. 245, 2009.

. Uma Editora Italiana na América Latina. O Grupo Abril (décadas de 1940 a 1970). Campinas: Ed. UNICAMP, 2016.

SCHUDSON, M. Descobrindo a Notícia. Uma História Social dos Jornais nos Estados Unidos. Petrópolis: Vozes, 2010.

SODRÉ, Muniz. A Narração do Fato. Notas para Uma Teoria do Acontecimento. Petrópolis: Vozes, 2009.

ULANOVSKY, Carlos. Paren las Rotativas. Historia de los Medios de Comunicación en la Argentina. Diarios, Revistas y Periodistas (1920-1969). Buenos Aires: Emecé, 2005. 